\title{
An Analysis of Technical Efficiency of Rice Production in Indonesia
}

\author{
Unggul Heriqbaldi ${ }^{1}$, Rudi Purwono ${ }^{1}$, Tri Haryanto ${ }^{1} \&$ Martha Ranggi Primanthi ${ }^{1}$ \\ ${ }^{1}$ Department of Economics, Airlangga University, Indonesia \\ Correspondence: Unggul Heriqbaldi, Department of Economics, Airlangga University, Airlangga street No. 4, \\ Surabaya, East Java, 60286, Indonesia. Tel: 62-818-0679-6025. E-mail: u.heriqbaldi@feb.unair.ac.id; \\ u.heriqbaldi@yahoo.com
}

\author{
Received: September 4, 2014 Accepted: October 9, 2014 Online Published: December 30, 2014 \\ doi:10.5539/ass.v11n3p91 \\ URL: http://dx.doi.org/10.5539/ass.v11n3p91
}

\begin{abstract}
The objectives of this paper are to estimate technical efficiency in rice production and to assess the effect of farm-specific socio-economic factors on the technical efficiency using survey data from 15 provinces in Indonesia, collected in 2008. A stochastic frontier production function model is used to estimate the technical efficiency of rice farms in each province, and using the model, the influence of socio-economic factors on efficiency is also measured. This study finds that there is a sizeable degree of variation of inefficiency between the 15 provinces. It also finds that factors like land size, income and source of funding are influential determinants of technical efficiency. In terms of age, it also found that younger farmers tend to be more efficient. Expanding the agricultural area, especially outside Java and Sumatera Islands, improving farmers' income and giving an incentive to young people to work in the agricultural sector will enhance technical efficiency and thus productivity, as well as the overall rice output
\end{abstract}

Keywords: rice production, technical efficiency, stochastic production function

\section{Introduction}

Currently, in the Indonesian context, the technical efficiency of rice farming is an important concern mainly because of its important role in maintaining domestic food security and as well as improving agricultural development. Rice is staple food that consumed by most Indonesian and the per capita consumption shows that it is higher compared to neighbouring countries. With a total population of approximately 235 million in 2007, the per capita rice consumption reached approximately 130-139 kilograms per year, while in Thailand and Japan the consumptions are 79 and 52 kilograms respectively (BPS, 2007).

Despite the important of rice sector in the Indonesian economy, this sector has been facing a significant challenge, especially in increasing the production at the level above the domestic consumption rate. Recent figures show that not only rice, but most of Indonesia's agricultural products, experience slower growth in total factor productivity (TFP) (World Bank, 2010). The agricultural TFP growth fell from 2.35 per cent per year in 1968-92 to annual contractions of 0.58 per cent from 1993 to 2001 (World Bank, 2010). Such conditions eventually contribute to the slow growth of job creations in rural areas.

Based on the above unfavourable condition especially in the productivity of rice farming and agricultural sector in Indonesia, it is then very important to improve the sectoral performance, not only in the context of food security and jobs creation, but also from the perspective of rural areas development. The objective of this paper is to quantify the technical efficiency of rice farm by using survey data from 15 provinces in Indonesia in 2008 , as well as to assess the factors that contribute to the technical efficiency. To achieve this objective, this paper employs stochastic production function and inefficiency effect model. In the context of literature on technical efficiency of rice farming in Indonesia, the present study extends the literatures in two ways. First, it utilizes the survey data from 15 provinces, which mainly become the major regions of rice farming in the country. Second, based on the quantification of technical efficiency, this paper tries to analyse both factors of production as well as socio-economic characteristics, contributes to the efficiency of rice farming.

This paper is organized as follows. Section 2 reviews the relevant literatures on efficiency studies in rice farming. Section 3 explains briefly the stochastic frontier model and specification of the functional forms. The empirical results are presented in section 4 and some conclusions are drawn in section 5. 


\section{A Brief of Literature}

Frontier models have been widely applied in agricultural studies (for example: Battese \& Coelli, 1992; Bravo-Ureta \& Pinheiro, 1993; and Xu \& Jeffrey, 1998). In the context of South and South-East Asian regions, rice production efficiency study has recieved a substantial attention (see for example: Balcombe et al., 2007; Coelli, et al., 2002; Dhungana, et al., 2004; Rahman, 2010; Rahman \& Rahman, 2009; Rahman, et al., 2009; Tan, et al., 2010; Wadud \& White, 2000; Yao \& Shively, 2007). In the case of India, some studies were also conducted, including by Battese et.al (1989), Battese and Coelli (1992), and Battese \& Coelli (1995). All three of these studies has a common approach which was using stochastic frontier production function. The results of these studies also showed some similarities, although in Battese \& Coelli (1995), the research not only focusing on the estimation of frontier production function, but also tries to develop the inefficiency effects model. From the inefficiency effects model, Battese \& Coelli (1995) found that age and education level of farmers, farm size and years of observation significantly affect agricultural production inefficiencies in the two villages were examined, namely Kanzara and Shirapur. While in the other villages, Aurepalle, the inefficiency were not significantly influenced by age and education variables farmers, farm size.

Bravo-Ureta and Pinheiro (1997) conducted a study on efforts to increase productivity by improving the efficiency of small-scale farming in the Dajabon region, Dominican Republic. The study uses two stages, where the first stage of Bravo-Ureta and Pinheiro (1997) estimate the stochastic production function to obtain the technical efficiency, allocative and economic efficiency levels by using maximum-likelihood method. In the second stage, Bravo-Ureta and Pinheiro (1997) used Tobit models to estimate the effect of various attributes of farmers on efficiency.

In the case study in China, Xu and Jeffrey (1998) and Tian and Wan (2000) estimate the efficiency of rice farming. Xu and Jeffrey (1998) try to analyse the differences in the production of conventional rice and hybrid rice farming by using a dual decomposition efficiency stochastic frontier models. The model involves several variables of which the location, chemical fertilizers, bio fertilizers, machinery, and pesticide. The results of the study showed significant differences in technical and allocative efficiency between conventional rice farming and the production of hybrid rice. Xu and Jeffrey (1998) and Tian and Wan (2000) found that education has a positive effect on technical efficiency of rice farming. Tian and Wan (2000) also found that multi-cropping index has a negative effect on the level of technical efficiency. Several other studies using the same method in analysing technical efficiency and inefficiency effects, such as Idiong (2007) in the case in Nigeria, Khan et al. (2010) in Bangladesh, and Khai and Yabe (2011) in Vietnam.

In other studies, Krasachat (2003) and Dhungana et al (2004) measure and investigate technical efficiency in Thailand and Nepal, respectively. Both use deterministic models to measure the level of technical efficiency, while the inefficiency effects obtained from the Tobit models. In the case of Thailand, Krasachat (2003) found the average overall technical efficiency is 0.71 and the variable of land affect significantly the level of efficiency. Meanwhile, in the case of Nepal, Dhungana et al (2004) found that differences in the level of inefficiency among farmers are the result of differences in the intensity of the use of resources such as seed, labour, fertilizer and mechanical equipment.

The same method is used by Javed et al (2010) in the analysis of rice and wheat farming in Pakistan. The results of the study revealed that the average technical efficiency in rice-wheat farming system is 0.83 , and the result from inefficiency models indicate that length of study, the number of contacts with advisor, and access to credit have a negative effect on inefficiency.

In the context of Indonesia, there is only a few empirical studies concerning technical efficiency of rice farming. Some that can be mentioned are Fabiosa, Jensen, and Yan (2004), Rada, Buccola, and Fuglie (2010), and Brazdik (2006). Brazdik (2006) evaluates the technical and scale efficiency of rice farms in West Java and to identify determinants affecting farms' efficiency and the result shows that farm size is one of the most important factors of farm's technical efficiency and that high land fragmentation was the main source of the technical inefficiency during the final period of the intensification era. Furthermore, Fabiosa et.al (2004) examine the impact of macroeconomic shocks on the efficiency of small farmers and conclude that productive efficiency declined by 7 to 22 percent during the crisis, largely because of a decline in technical efficiency and a relatively large volatility in efficiency.

However, in the context of Indonesia, there is no study that compare the rice farming technical efficiency of each region in Indonesia and identify the common and specific characteritics which influence its technical efficiency. Consequently, this paper contributes to fill the the current gap by estimating and comparing technical efficiency 
among regions and identify the common and specific characteristics which contribute to the technical efficiency in each region.

\section{Model and Data}

\subsection{The Basic Model}

The stochastic frontier model which also called composed error model was introduced by Aigner et al. (1977) and Meeusen and van den Broeck (1977). The basic model of stochastic frontier can be represented as follows.

$$
y_{i}=g\left(x_{i}, \beta\right)+\varepsilon_{i} \text { for } \mathrm{i}=1,2, \ldots, \mathrm{N}
$$

where $y=$ output, $x=$ input vector, $\beta=$ parameter vector, $\varepsilon=$ error term, $i=$ firm or production unit. The error term $\mathcal{E}$, consists of two independent components,

$$
\varepsilon_{i}=v_{i}-u_{i}
$$

where $v_{i}$ is two-sided error term which represents statistical noise which is assumed to be i.i.d $N\left(0, \sigma_{v}^{2}\right)$ and $u_{i} \geq$ 0 is one sided error term that represents technical inefficiency, assumed to be independent to $v_{i}$ and $x_{i}$. Another assumption is that error component $u_{i}=\left|\mathrm{U}_{\mathrm{i}}\right|$, where $\mathrm{U}_{\mathrm{i}}$ is i.i.d $N\left(0, \sigma_{u}^{2}\right)$. This assumption implies that $u_{i}$ is half-normal. However, the assumption can be replaced by other assumption such as truncated-normal (Stevenson, 1980; Battese and Coelli, 1992) and two-parameter gamma (Greene, 1990).

Based on those assumptions, the model can be estimated using Maximum-Likelihood Estimation (MLE). Aigner et al. (1977) derives log likelihood function based on the following:

$$
\ln \left(y_{i}\right)=g\left(x_{i}, \beta\right)+v_{i}-u_{i}
$$

Furthermore, ALS (1977) expresses the likelihood function in the form of two variance parameters, which are $\sigma^{2}=\sigma_{u}^{2}+\sigma_{v}^{2}$ and $\lambda=\sigma_{u} / \sigma_{v} . \lambda$ is an indicator of variability in two sources' random errors, which then differentiate one production unit to the other. The likelihood function therefore can be expressed as follow.

$$
\ln L\left(y \mid \beta, \lambda, \sigma^{2}\right)=N \ln \frac{\sqrt{2}}{\sqrt{\Pi}}+N \ln \sigma^{-1}+\sum_{i=1}^{N} \ln \left[1-F\left(\varepsilon_{i} \lambda \sigma^{-1}\right)\right]-\frac{1}{2 \sigma^{2}} \sum_{i=1}^{N} \varepsilon_{i}^{2}
$$

where, $\varepsilon_{i}=y_{i}-x_{i} \beta$ and $\mathrm{F}$ are standard normal conditional distribution function (cdf). The ML estimator is derived from the maximization of (4) with respect to the parameters $\beta, \lambda, \sigma$.

If $y$ in logarithm, hence the technical efficiency of production unit $i$ can be expressed as follow

$$
T E_{i}=\exp \left(-u_{i}\right)
$$

and technical inefficiency is $1-T E_{i}$. The prediction of the above technical efficiency requires estimates of the $u_{i}$. The best predictor for $u_{i}$ is conditional expected value of $u_{i}$ given $\varepsilon_{i}$. This condition was stated and applied in the stochastic frontier model of Jondrow et.al (1982). Jondrow et.al (1982) show that

$$
E(u \mid \varepsilon)=\sigma_{*}\left[\frac{f(\varepsilon \lambda / \sigma)}{1-F(\varepsilon \lambda / \sigma)}-\left(\frac{\varepsilon \lambda}{\sigma}\right)\right]
$$

where $\varepsilon \lambda / \sigma=-\mu_{*} / \sigma_{*}$ and $\lambda=\sigma_{u} / \sigma_{v}$, while $\mathrm{f}$ and $\mathrm{F}$ are $c d f$ respectively. Since $\mu_{*}$ and $\sigma_{*}$ are unobservable, hence the parameters can be replaced by the estimates of respective parameters. Referring to Battese and Coelli (1988), the technical efficiency of production unit of $i$ is

$$
T E=E\left[\exp \left(-u_{i} \mid \varepsilon_{i}\right)\right]=\left\{\frac{1-\Phi\left[\sigma_{*}-\left(\mu_{i}^{*} / \sigma_{*}\right)\right]}{1-\Phi\left(-\mu_{i}^{*} / \sigma_{*}\right)}\right\} \exp \left(-\mu_{i}^{*}+\frac{1}{2} \sigma_{*}^{2}\right)
$$

where $\Phi(\cdot)$ is the $c d f$.

\subsection{Functional Forms and Variables}

This paper will use the most appropriate functional forms by employing the log likelihood ratio test to the Cobb-Douglas and translog models. The Cobb-Douglas specification is presented as follow.

$$
y_{i}=\beta_{0} \prod_{j=1}^{n} x_{i j}^{\beta_{i j}} e^{\varepsilon_{i}} \quad \text { For } i=1,2, \ldots, n
$$

where $\mathrm{y}=$ output, $x_{j}=$ the $j$-th input, $i=i$-th farmer, $\varepsilon_{i}=v_{i}-u_{i}$, and $\beta_{0}, \beta_{i j}=$ parameters. Transforming into logarithm form yields; 


$$
\ln y_{i}=\ln \beta_{0} \sum_{j=1}^{n} \beta_{i j} \ln x_{i j}+v_{i}-u_{i}
$$

The detail model specification for the case of paddy production is:

$$
\begin{gathered}
\ln \left(y_{i}\right)=\ln \beta_{0}+\beta_{1} \ln \left(\text { land }_{i}\right)+\beta_{2} \ln \left(\text { seed }_{i}\right)+\beta_{3} \ln \left(\text { fertilizer }_{i}\right)+\beta_{4} \ln \left(\text { pesticide }_{i}\right)+\beta_{5} \ln \left(\text { labor }_{i}\right)+ \\
\beta_{6}\left(\text { cost }_{i}\right)+v_{i}-u_{i}
\end{gathered}
$$

where $y$ represents the quantity of freshly threshed rice paddy (in tonnes); land $d_{i}$ is the harvest area (in hectares); seed $_{i}$ is quantity of seeds used in the farming areas (in kilograms); fertilizer $_{i}$ is fertilizer (in kilograms); pesticide $e_{i}$ is pesticide applied (in kilograms); labor $_{i}$ is hired labourers input (person-days); family $_{i}$ labour input by family (person-days); cost $t_{i}$ is dummy variable for other cost of rice farming, such as land rent, farming equipment, credit interest, land tax, fuels, and others $(\mathrm{D}=1$, if other costs are positive, $\mathrm{D}=0$ otherwise); $\quad v_{i}$ is stochastic noise, assumed to be i.i.d $N\left(0, \sigma_{v}^{2}\right) ; u_{i}$ is non-negative random variable which is called inefficiency effect, assumed to be distributed as absolute value from $N\left(0, \sigma_{u}^{2}\right)$; and $\beta$ is unknown parameter to be estimated along with the variance parameters, which is formulated in the form: $\sigma^{2}=\sigma_{u}^{2}+\sigma_{v}^{2}$ and $\lambda=\sigma_{u} / \sigma_{v}$.

The second specification is the translog model, which is given by:

$$
\ln y_{i}=\alpha_{0}+\sum_{j=1}^{6} \alpha_{j i} \ln x_{j i}+0.5 \sum_{j=1}^{6} \alpha_{j i} \ln x_{j i}^{2}+\sum_{j=1}^{6} \quad \sum_{k}^{6} \alpha_{j k} \ln x_{j i} \ln x_{k i}+v_{i}-u_{i}
$$

where the variables are as previously defined.

As a special case of translog model, the Cobb-Douglass functional form imposes restrictions on the technology by imposing constant production elasticity and elasticity of input substitution equals to unity. Therefore, this paper will test the Cobb-Douglas against the translog function to determine whether it is an adequate representation of the data.

Based on the appropriate model, the next procedure will be hypothesis test for $\lambda$ which will determine whether there is inefficiency effect or not. Given the result of hypothesis test procedure, the technical inefficiency model is defined as follow (Battese \& Coelli, 1995):

$$
u_{i t}=\delta_{0}+\sum_{j=1}^{11} \delta_{j} Z_{j i}
$$

Where the $\delta_{j}$ s are unknown parameters; $Z_{1}$ is income of farmer million rupiah per month); $Z_{2}$ is dummy for farmer's education attainment ( 1 if farmer finishes high school, 0 otherwise); $Z_{3}$ is farmer's age (year); $Z_{4}$ is dummy for farmer's other job ( 1 if farmer has other job, 0 otherwise); $Z_{5}$ is dummy for irrigation facility ( 1 if rice field irrigated, 0 otherwise); $Z_{6}$ is dummy for financial source for farming ( 1 if self-funding, 0 otherwise), $Z_{7}$ is dummy for government assistance ( 1 if government assisted, 0 otherwise); $Z_{8}$ is dummy for dry season ( 1 if production in drought condition, 0 otherwise); $Z_{9}$ is dummy for rainy season ( 1 if production in rainy season, 0 otherwise); $Z_{10}$ is dummy for cultivating area (1 if area more than $5000 \mathrm{~m} 2,0$ otherwise); and $Z_{11}$ the ratio of labour per hectare.

\subsection{Descriptive Statistics}

Table 1. Sample distribution based on province

\begin{tabular}{lll}
\hline No & Province & Farm Sample (n) \\
\hline 1 & Nanggroe Aceh Darussalam (NAD) & 186 \\
2 & Sumatera Utara (SUMUT) & 274 \\
3 & Sumatera Barat (SUMBAR) & 217 \\
4 & Sumatera Selatan (SUMSEL) & 238 \\
5 & Lampung & 230 \\
6 & Jawa Barat (JABAR) & 345 \\
7 & Jawa Tengah (JATENG) & 337 \\
8 & Jawa Timur (JATIM) & 339 \\
9 & Banten & 216 \\
10 & Bali & 133 \\
11 & Nusa Tenggara Barat (NTB) & 185 \\
12 & Kalimantan Barat (KALBAR) & 152 \\
13 & Kalimantan Selatan (KALSEL) & 199 \\
14 & Sulawesi Tengah (SULTENG) & 128 \\
15 & Sulawesi Selatan (SULSEL) & 275 \\
\hline Total & & 3454 \\
\hline
\end{tabular}


This study uses data from the 3454 rice farmers in 15 provinces in Indonesia based on a survey of business cost structure of rice plants (SOUTP) conducted by the Central Statistics Agency (BPS) of Indonesia in 2008.

Descriptive statistics of all variables included in the model are presented in Table 2 . The descriptive statistics are calculated based on provincial basis. From production perspective, the production of rice in 15 provinces is at an average of 2 tons per hectare, where Sumatera and Sulawesi became the two highest rice producers. The average labour use in all provinces was approximately 51 person-days per hectare, while in terms of fertilizer used the mean value was 177 kilograms per hectare. From age perspective, most of age of the farmers is more than 45 years.

Table 2. Descriptive statistics of all variables included in the stochastic frontier production models and inefficiency models

\begin{tabular}{|c|c|c|c|c|c|c|c|c|c|c|}
\hline Province & Component & Output & Land & Seed & Fertilizer & Pesticide & Labour & $\begin{array}{l}\text { Other } \\
\text { cost }\end{array}$ & Other income & Age \\
\hline \multirow[t]{5}{*}{ NAD } & $\mathrm{N}$ & 179 & 179 & 179 & 179 & 179 & 179 & 179 & 179 & 179 \\
\hline & Min & 210 & 400 & 3 & 8 & 2 & 8 & 15 & 159 & 21 \\
\hline & $\operatorname{Max}$ & 4600 & 12500 & 100 & 400 & 1500 & 103 & 3700 & 8735 & 86 \\
\hline & Mean & 1218 & 2524 & 19 & 78 & 184 & 29 & 612 & 1736 & 50 \\
\hline & Stdev & 874 & 1882 & 15 & 62 & 231 & 15 & 660 & 1423 & 12 \\
\hline \multirow[t]{5}{*}{ SUMUT } & $\mathrm{N}$ & 638 & 638 & 638 & 638 & 638 & 638 & 638 & 638 & 638 \\
\hline & Min & 220 & 430 & 2 & 5 & 3 & 4 & 2 & 38 & 17 \\
\hline & $\operatorname{Max}$ & 35000 & 100000 & 800 & 2100 & 64000 & 499 & 22572 & 44553 & 85 \\
\hline & Mean & 2918 & 6387 & 39 & 190 & 970 & 47 & 1136 & 4438 & 49 \\
\hline & Stdev & 3075 & 7689 & 53 & 195 & 3711 & 32 & 1449 & 5151 & 12 \\
\hline \multirow[t]{5}{*}{ SUMBAR } & $\mathrm{N}$ & 196 & 196 & 196 & 196 & 196 & 196 & 196 & 196 & 196 \\
\hline & Min & 160 & 648 & 3 & 7 & 2 & 10 & 2 & 60 & 23 \\
\hline & Max & 4644 & 14000 & 68 & 570 & 7000 & 201 & 6785 & 8007 & 88 \\
\hline & Mean & 1410 & 4125 & 22 & 94 & 367 & 39 & 714 & 1940 & 50 \\
\hline & Stdev & 937 & 2704 & 14 & 88 & 960 & 27 & 798 & 1658 & 14 \\
\hline \multirow[t]{5}{*}{ SUMSEL } & $\mathrm{N}$ & 484 & 484 & 484 & 484 & 484 & 484 & 484 & 484 & 484 \\
\hline & Min & 450 & 900 & 2 & 23 & 50 & 9 & 53 & 63 & 18 \\
\hline & Max & 16000 & 40000 & 245 & 2150 & 120000 & 292 & 5418 & 21715 & 85 \\
\hline & Mean & 3608 & 9926 & 56 & 241 & 3391 & 74 & 817 & 5906 & 46 \\
\hline & Stdev & 2476 & 7362 & 45 & 174 & 6666 & 70 & 824 & 4704 & 12 \\
\hline \multirow[t]{5}{*}{ LAMPUNG } & $\mathrm{N}$ & 504 & 504 & 504 & 504 & 504 & 504 & 504 & 504 & 504 \\
\hline & Min & 250 & 400 & 3 & 15 & 2 & 8 & 7 & 26 & 22 \\
\hline & $\operatorname{Max}$ & 12200 & 27500 & 150 & 4100 & 16000 & 258 & 7166 & 15038 & 93 \\
\hline & Mean & 2238 & 5013 & 21 & 273 & 665 & 55 & 709 & 2792 & 49 \\
\hline & Stdev & 1726 & 3831 & 17 & 299 & 1080 & 42 & 887 & 2342 & 13 \\
\hline \multirow[t]{5}{*}{ JABAR } & $\mathrm{N}$ & 1454 & 1454 & 1454 & 1454 & 1454 & 1454 & 1454 & 1454 & 1454 \\
\hline & Min & 112 & 280 & 2 & 5 & 2 & 6 & 2 & 2 & 15 \\
\hline & $\operatorname{Max}$ & 25800 & 43000 & 105 & 2900 & 45000 & 424 & 25325 & 50137 & 90 \\
\hline & Mean & 1757 & 3730 & 13 & 185 & 1022 & 52 & 647 & 2232 & 51 \\
\hline & Stdev & 2383 & 4785 & 13 & 241 & 2838 & 39 & 1422 & 3837 & 12 \\
\hline \multirow[t]{5}{*}{ JATENG } & $\mathrm{N}$ & 1320 & 1320 & 1320 & 1320 & 1320 & 1320 & 1320 & 1320 & 1320 \\
\hline & Min & 90 & 375 & 2 & 10 & 2 & 7 & 2 & 3 & 24 \\
\hline & $\operatorname{Max}$ & 12000 & 20000 & 150 & 1830 & 20000 & 297 & 10162 & 25141 & 88 \\
\hline & Mean & 1301 & 2657 & 14 & 194 & 424 & 40 & 391 & 1421 & 51 \\
\hline & Stdev & 1185 & 2247 & 12 & 237 & 959 & 26 & 682 & 1603 & 12 \\
\hline \multirow[t]{5}{*}{ JATIM } & $\mathrm{N}$ & 1197 & 1197 & 1197 & 1197 & 1197 & 1197 & 1197 & 1197 & 1197 \\
\hline & Min & 99 & 260 & 2 & 6 & 2 & 4 & 2 & 7 & 15 \\
\hline & $\operatorname{Max}$ & 22000 & 35000 & 200 & 5800 & 20000 & 344 & 13310 & 27753 & 98 \\
\hline & Mean & 1683 & 3238 & 17 & 228 & 278 & 43 & 470 & 2020 & 51 \\
\hline & Stdev & 1698 & 2977 & 17 & 308 & 696 & 34 & 761 & 2290 & 12 \\
\hline \multirow[t]{5}{*}{ BANTEN } & $\mathrm{N}$ & 342 & 342 & 342 & 342 & 342 & 342 & 342 & 342 & 342 \\
\hline & Min & 150 & 400 & 2 & 8 & 2 & 12 & 4 & 67 & 12 \\
\hline & Max & 9800 & 25700 & 75 & 900 & 1800 & 220 & 4612 & 18421 & 90 \\
\hline & Mean & 1569 & 3287 & 11 & 113 & 258 & 47 & 308 & 2169 & 48 \\
\hline & Stdev & 1330 & 3087 & 10 & 111 & 269 & 29 & 453 & 2301 & 12 \\
\hline \multirow[t]{5}{*}{ BALI } & $\mathrm{N}$ & 117 & 117 & 117 & 117 & 117 & 117 & 117 & 117 & 117 \\
\hline & Min & 180 & 300 & 2 & 10 & 5 & 12 & 17 & 277 & 29 \\
\hline & Max & 9000 & 18000 & 70 & 1400 & 2400 & 194 & 7384 & 13477 & 81 \\
\hline & Mean & 2105 & 3793 & 17 & 197 & 273 & 53 & 1071 & 2659 & 51 \\
\hline & Stdev & 1580 & 2612 & 12 & 201 & 315 & 38 & 1362 & 2374 & 11 \\
\hline \multirow[t]{2}{*}{ NTB } & $\mathrm{N}$ & 174 & 174 & 174 & 174 & 174 & 174 & 174 & 174 & 174 \\
\hline & Min & 160 & 400 & 2 & 15 & 50 & 9 & 8 & 51 & 20 \\
\hline
\end{tabular}




\begin{tabular}{|c|c|c|c|c|c|c|c|c|c|c|}
\hline Province & Component & Output & Land & Seed & Fertilizer & Pesticide & Labour & $\begin{array}{l}\text { Other } \\
\text { cost }\end{array}$ & Other income & Age \\
\hline & $\operatorname{Max}$ & 8100 & 20000 & 160 & 770 & 15000 & 171 & 2800 & 15604 & 90 \\
\hline & Mean & 2220 & 5365 & 35 & 168 & 735 & 48 & 560 & 2940 & 47 \\
\hline & Stdev & 1677 & 3972 & 29 & 135 & 1772 & 31 & 507 & 2709 & 13 \\
\hline \multirow[t]{5}{*}{ KALBAR } & $\mathrm{N}$ & 163 & 163 & 163 & 163 & 163 & 163 & 163 & 163 & 163 \\
\hline & Min & 450 & 900 & 5 & 15 & 2 & 12 & 10 & 535 & 26 \\
\hline & $\operatorname{Max}$ & 8730 & 35000 & 110 & 550 & 15000 & 391 & 1730 & 17815 & 82 \\
\hline & Mean & 2106 & 6127 & 22 & 129 & 1923 & 96 & 191 & 4068 & 48 \\
\hline & Stdev & 1304 & 4142 & 14 & 90 & 2116 & 69 & 263 & 2868 & 12 \\
\hline \multirow[t]{5}{*}{ KALSEL } & $\mathrm{N}$ & 292 & 292 & 292 & 292 & 292 & 292 & 292 & 292 & 292 \\
\hline & Min & 189 & 723 & 4 & 15 & 2 & 8 & 10 & 11 & 19 \\
\hline & $\operatorname{Max}$ & 7430 & 20230 & 103 & 720 & 6000 & 202 & 3930 & 13814 & 82 \\
\hline & Mean & 1624 & 4539 & 24 & 130 & 933 & 61 & 625 & 2295 & 46 \\
\hline & Stdev & 1135 & 3026 & 16 & 105 & 1025 & 33 & 682 & 2099 & 12 \\
\hline \multirow[t]{5}{*}{ SULTENG } & $\mathrm{N}$ & 146 & 146 & 146 & 146 & 146 & 146 & 146 & 146 & 146 \\
\hline & Min & 257 & 500 & 3 & 10 & 40 & 4 & 27 & 61 & 20 \\
\hline & $\operatorname{Max}$ & 30000 & 60000 & 480 & 1800 & 53100 & 316 & 36300 & 40299 & 81 \\
\hline & Mean & 3162 & 7683 & 50 & 252 & 3014 & 35 & 2532 & 4071 & 46 \\
\hline & Stdev & 4056 & 8117 & 53 & 266 & 5709 & 29 & 5052 & 5185 & 13 \\
\hline \multirow[t]{5}{*}{ SULSEL } & $\mathrm{N}$ & 729 & 729 & 729 & 729 & 729 & 729 & 729 & 729 & 729 \\
\hline & Min & 114 & 300 & 2 & 8 & 4 & 6 & 10 & 30 & 19 \\
\hline & $\operatorname{Max}$ & 17470 & 30000 & 240 & 1450 & 6500 & 186 & 17646 & 26090 & 85 \\
\hline & Mean & 2574 & 5403 & 23 & 179 & 547 & 51 & 1664 & 2755 & 47 \\
\hline & Stdev & 2208 & 4456 & 21 & 175 & 691 & 25 & 2240 & 2740 & 13 \\
\hline \multicolumn{2}{|c|}{ Mean value of each variables } & 2099.53 & 4919.80 & 25.53 & 176.73 & 998.93 & 51.33 & 829.80 & \begin{tabular}{|l|}
2896.13 \\
\end{tabular} & 48.67 \\
\hline
\end{tabular}

Note, $N$ : number of farm samples; stdev: standard deviation

\section{Empirical Result}

\subsection{Production Frontier Estimates}

A likelihood ratio (LR) test can be employed to determine which model specification is better. In this study, the LR test was conducted to compare the Cobb-Douglas production function model against the translog model. The null hypothesis of the test is that the appropriate model is Cobb-Douglas production function, while the alternative hypothesis is that the translog model is more representative in explaining production function of rice farming in all 15 provinces. The chi-square values obtained from the test are presented in Table 3 . The test result shows that in most of the cases the null hypothesis was rejected (except for Bali, Nusa Tenggara Barat, and Kalimantan Barat) and it was concluded that in 12 provinces, the translog specification fitted the data better than the Cobb-Douglas counterpart.

Table 3. Likelihood ratio test on Cobb-Douglas production function model against the translog model

\begin{tabular}{|c|c|c|c|c|c|c|c|}
\hline \multirow{2}{*}{ No } & \multirow{2}{*}{ Province } & \multicolumn{2}{|c|}{ Log Likelihood Function } & \multirow{2}{*}{ LR-stat } & \multirow{2}{*}{$\begin{array}{c}\text { Critical Value } \\
\alpha=0.05\end{array}$} & \multirow{2}{*}{ Decision } & \multirow{2}{*}{ Appropriate Model } \\
\hline & & Cobb-Douglas & Translog & & & & \\
\hline 1 & NAD & 33.62 & 75.02 & 82.81 & 32.67 & Reject $\mathrm{H}_{0}$ & Translog \\
\hline 2 & SUMUT & 44.36 & 67.66 & 46.61 & 32.67 & Reject $\mathrm{H}_{0}$ & Translog \\
\hline 3 & SUMBAR & 10.11 & 25.92 & 31.61 & 32.67 & Reject $\mathrm{H}_{0}$ & Translog \\
\hline 4 & SUMSEL & 7.95 & 69.53 & 123.16 & 32.67 & Reject $\mathrm{H}_{0}$ & Translog \\
\hline 5 & LAMPUNG & -79.74 & -54.18 & 51.12 & 32.67 & Reject $\mathrm{H}_{0}$ & Translog \\
\hline 6 & JABAR & 136.66 & 170.72 & 68.13 & 32.67 & Reject $\mathrm{H}_{0}$ & Translog \\
\hline 7 & JATENG & 483.59 & 665.55 & 363.94 & 32.67 & Reject $\mathrm{H}_{0}$ & Translog \\
\hline 8 & JATIM & 1.85 & 38.92 & 74.14 & 32.67 & Reject $\mathrm{H}_{0}$ & Translog \\
\hline 9 & BANTEN & 9.91 & 36.16 & 52.50 & 32.67 & Reject $\mathrm{H}_{0}$ & Translog \\
\hline 10 & BALI & 36.21 & 33.35 & -5.71 & 32.67 & Accept $\mathrm{H}_{0}$ & Cobb-Douglas \\
\hline 11 & NTB & -24.35 & -12.43 & 23.84 & 32.67 & Accept $\mathrm{H}_{0}$ & Cobb-Douglas \\
\hline 12 & KALBAR & 96.59 & -34.99 & -263.14 & 32.67 & Accept $\mathrm{H}_{0}$ & Cobb-Douglas \\
\hline 13 & KALSEL & 30.91 & 57.62 & 53.42 & 32.67 & Reject $\mathrm{H}_{0}$ & Translog \\
\hline 14 & SULTENG & 0.40 & 35.95 & 71.10 & 32.67 & Reject $\mathrm{H}_{0}$ & Translog \\
\hline 15 & SULSEL & 43.42 & 88.39 & 89.94 & 32.67 & Reject $\mathrm{H}_{0}$ & Translog \\
\hline
\end{tabular}

Based on the above result, the maximum likelihood estimates of the parameters from the most appropriate model are presented in Table 4. 
Table 4. Maximum-likelihood estimates for parameters of the stochastic frontier production models in 15 provinces

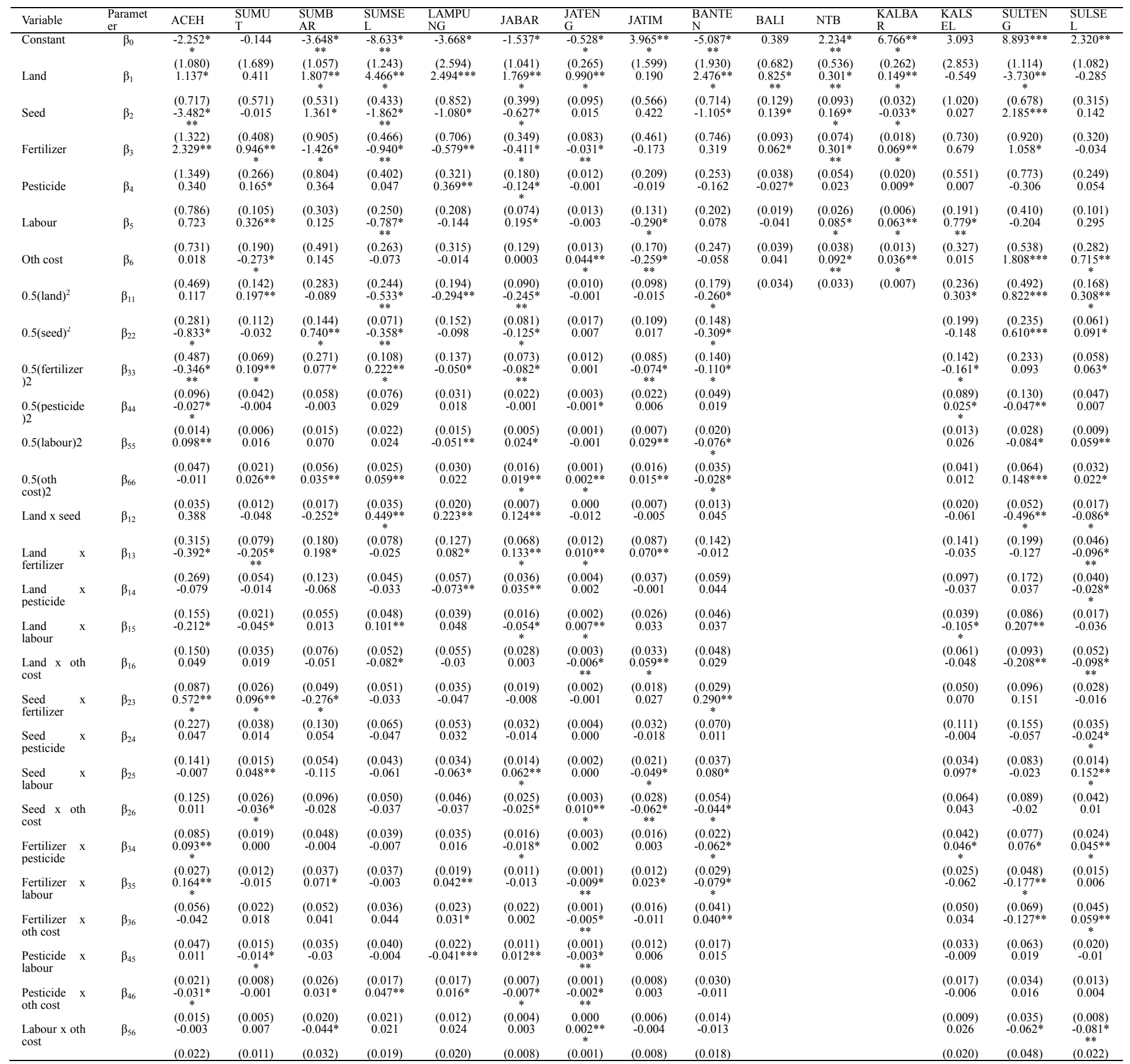

$(* * *),(* *)(*)$ indicates respectively that the value of the statistic is significant at 1,5 and 10 percent

The result of parameter estimates for land area variable shows a positive and statistically significant coefficient in 11 provinces, which means that an increase in land area will have a positive impact on rice farming. Since the coefficient is obtained from the log-log model, then the coefficient can be interpreted as land area elasticity of rice farming. This elasticity varies in each province, and is in the range 0.3 to 4.4 . It means that in some provinces the relationship between the land area and rice farming is inelastic, but in some other provinces, is quite elastic. The coefficients of square of land size are negatively significant in the case of SUMSEL, LAMPUNG, JABAR, and BANTEN, which imply that the rice farming function in those province exhibits 
diminishing return. This means that adding more land area will reduce the marginal productivity of land at some point.

An interesting result is shown by the coefficients of fertilizer in 11 provinces. Although the coefficients are statistically significant, the signs are not consistent from one province to other. For example, in the case of SUMSEL, LAMPUNG, JABAR, and JATENG, the coefficients are negative, which mean that an increase in the use of fertilizer in the production process will have a negative impact on rice farming. One possible explanation for this result is that the fatigue condition of land. It is because all the provinces above have intensively used fertilizer in rice farming more than other province. Hence the impact of additional use of fertilizer might harm the productivity capacity of rice farming. This notion is also supported by the coefficients of square of fertilizer that are negatively significant in 5 provinces, implying diminishing return.

In the case of pesticide use in rice farming process, the coefficients are not significant in most of all provinces, except for SUMUT, LAMPUNG, JABAR, BALI, and KALBAR. The coefficients' sign also show mixed result but in all, the pesticide elasticity of rice farming is very low.

Another interesting result is shown by coefficient of labour, where there are only 7 provinces in which labour has an impact to rice farming. Even, in the case of 2 provinces, SUMSEL and JATIM, the labour coefficient is negative, implying that an increase in labour hour in production process will have a negative impact on output. Moreover, in the case of JATIM, it can be seen that the use of labour in the paddy production exhibits the minimum function since the parameter of squared land is positive. It may be concluded that at some stage after passing the minimum amount of labour required, an increase of this input will increase the output.

Additionally, the cross effect coefficient indicates the relationship between two inputs. The result shows that generally land and seed, land and fertilizer, seed and fertilizer, seed and labour, fertilizer and pesticide, fertilizer and labour are complementary inputs. Whereas, on average land and pesticide, land and labour, land and other cost, seed and pesticide, seed and other cost, pesticide and other cost and labour and other cost are substitution inputs.

\subsection{Inefficiency Effect Estimates}

Moving forward into the analysis of inefficiency model, it is required to identify whether the inefficiency model can accurately represent the rice production function characteristics. In order to meet that condition, it is necessary to conduct Likelihood Ratio (LR) test. In LR test, the efficiency model becomes the unrestricted model, whereas the standard model (without inefficiency effect) becomes the restricted one. The result of the LR test is represented in Table 5. The LR test shows that inefficiency effect exists in the rice stochastic frontier production model in all provinces. The inefficiency effect is also supported by the value of gamma parameter which is quite big and statistically significant.

Table 5. LR test efficiency model versus standard model

\begin{tabular}{|c|c|c|c|c|c|}
\hline \multirow{2}{*}{ Province } & \multirow{2}{*}{ LR stat } & \multicolumn{2}{|c|}{ Critical Value* } & \multirow{2}{*}{ Decision } & \multirow{2}{*}{ Remark } \\
\hline & & df & $\alpha=0.01$ & & \\
\hline $\mathrm{ACEH}$ & 125.729 & 13 & 27.026 & Reject $\mathrm{H}_{0}$ & inefficiency effect \\
\hline SUMUT & 164.938 & 13 & 27.026 & Reject $\mathrm{H}_{0}$ & inefficiency effect \\
\hline SUMBAR & 47.208 & 13 & 27.026 & Reject $\mathrm{H}_{0}$ & inefficiency effect \\
\hline SUMSEL & 151.908 & 13 & 27.026 & Reject $\mathrm{H}_{0}$ & inefficiency effect \\
\hline LAMPUNG & 185.152 & 13 & 27.026 & Reject $\mathrm{H}_{0}$ & inefficiency effect \\
\hline JABAR & 495.310 & 13 & 27.026 & Reject $\mathrm{H}_{0}$ & inefficiency effect \\
\hline JATENG & 1042.368 & 13 & 27.026 & Reject $\mathrm{H}_{0}$ & inefficiency effect \\
\hline JATIM & 376.815 & 13 & 27.026 & Reject $\mathrm{H}_{0}$ & inefficiency effect \\
\hline BANTEN & 133.867 & 13 & 27.026 & Reject $\mathrm{H}_{0}$ & inefficiency effect \\
\hline BALI & 66.378 & 13 & 27.026 & Reject $\mathrm{H}_{0}$ & inefficiency effect \\
\hline NTB & 66.717 & 13 & 27.026 & Reject $\mathrm{H}_{0}$ & inefficiency effect \\
\hline KALBAR & 306.246 & 13 & 27.026 & Reject $\mathrm{H}_{0}$ & inefficiency effect \\
\hline KALSEL & 85.566 & 13 & 27.026 & Reject $\mathrm{H}_{0}$ & inefficiency effect \\
\hline SULTENG & 45.231 & 13 & 27.026 & Reject $\mathrm{H}_{0}$ & inefficiency effect \\
\hline SULSEL & 179.553 & 13 & 27.026 & Reject $\mathrm{H}_{0}$ & inefficiency effect \\
\hline
\end{tabular}

The maximum likelihood estimates of inefficiency effects model is presented in Table 6 . From the table it can be seen that the coefficients of income in all provinces, are found to have the expected signs. The income variable has a significant positive association, indicating that as the income of farmer increased, the farmer has the ability to use better inputs in the production process, which in turn increase the production efficiency. 
In the context of education variables, the estimation results show that in almost all provinces, the coefficient of education has no significant effect on the level of efficiency of rice farming. There are only 4 provinces that show a negative effect of education on rice farming efficiency. These results may be attributed to the age background of the majority of farmers that are above 45 years, so that the effect of education is not significant on the production efficiency changes.

The analysis of the education variable above is confirmed by the estimates of age coefficient, which show that the age variable has a significant negative association, indicating that younger farmers tend to be more efficient. Moreover, having another job for farmer has influence to the production efficiency only in a few provinces. In some provinces such as SUMSEL and JATENG, having another job improves the efficiency through improvement of income and skill of farmer, while in other provinces, the job in fact has a negative impact on efficiency.

Table 6. Maximum-likelihood estimates for parameters of the inefficiency effects model

\begin{tabular}{|c|c|c|c|c|c|c|c|c|c|c|c|c|c|c|c|c|}
\hline Variable & $\begin{array}{c}\text { Parame } \\
\text { ter }\end{array}$ & ACEH & $\begin{array}{c}\text { SUMU } \\
\text { T } \\
\end{array}$ & $\begin{array}{c}\text { SUMB } \\
\text { AR }\end{array}$ & $\begin{array}{c}\text { SUMS } \\
\text { EL }\end{array}$ & $\begin{array}{c}\text { LAMPU } \\
\text { NG } \\
\end{array}$ & $\begin{array}{c}\text { JABA } \\
\mathbf{R} \\
\end{array}$ & $\begin{array}{c}\text { JATE } \\
\text { NG } \\
\end{array}$ & $\begin{array}{c}\text { JATI } \\
\text { M } \\
\end{array}$ & $\begin{array}{c}\text { BANT } \\
\text { EN }\end{array}$ & BALI & NTB & $\begin{array}{c}\text { KALB } \\
\text { AR }\end{array}$ & $\begin{array}{c}\text { KALS } \\
\text { EL }\end{array}$ & $\begin{array}{c}\text { SULTE } \\
\text { NG }\end{array}$ & $\begin{array}{c}\text { SULS } \\
\text { EL }\end{array}$ \\
\hline \multirow{3}{*}{ Income } & \multirow{3}{*}{$\delta_{1}$} & -0.220 & -0.394 & $-0.200^{*}$ & -0.187 & $-0.198^{* *}$ & -0.250 & -0.439 & -0.452 & $-0.270^{*}$ & -0.372 & $-0.19^{*}$ & $\begin{array}{l}-0.709^{*} \\
\end{array}$ & -0.091 & $-0.127^{*}$ & -0.321 \\
\hline & & $* * *$ & $* * *$ & $* *$ & $* * *$ & $*$ & $* * *$ & $* * *$ & $* * *$ & $* *$ & $* * *$ & $* *$ & $* *$ & $* * *$ & $* *$ & $* * *$ \\
\hline & & $(0.063)$ & $(0.117)$ & $(0.038)$ & $(0.033)$ & $(0.036)$ & $(0.038)$ & $(0.023)$ & $(0.101)$ & $(0.093)$ & $(0.137)$ & $\begin{array}{c}(0.042 \\
)\end{array}$ & $(0.023)$ & $(0.018)$ & $(0.037)$ & $(0.063)$ \\
\hline \multirow[t]{2}{*}{ Education } & \multirow[t]{2}{*}{$\delta_{2}$} & -0.041 & -0.004 & $\begin{array}{l}0.166^{*} \\
*\end{array}$ & $0.223^{*}$ & 0.097 & 0.078 & 0.087 & $\begin{array}{c}0.215^{*} \\
*\end{array}$ & 0.063 & 0.170 & -0.180 & -0.025 & -0.038 & -0.032 & $0.112 *$ \\
\hline & & $(0.127)$ & $(0.095)$ & $(0.092)$ & $(0.146)$ & $(0.125)$ & $(0.110)$ & $(0.074)$ & $(0.119)$ & $(0.298)$ & $(0.164)$ & $\begin{array}{c}(0.216 \\
)\end{array}$ & $(0.037)$ & $(0.072)$ & $(0.133)$ & $(0.085)$ \\
\hline \multirow[t]{2}{*}{ Age } & \multirow[t]{2}{*}{$\delta_{3}$} & 0.004 & $\begin{array}{c}0.019^{*} \\
* *\end{array}$ & $\begin{array}{l}0.010^{*} \\
* *\end{array}$ & $\begin{array}{c}0.006^{*} \\
* *\end{array}$ & $0.010^{* * *}$ & $\begin{array}{c}0.015^{*} \\
* *\end{array}$ & $\begin{array}{c}0.006^{*} \\
* *\end{array}$ & $\begin{array}{c}0.016^{*} \\
* *\end{array}$ & $\begin{array}{l}0.007^{*} \\
*\end{array}$ & 0.004 & $\begin{array}{l}0.011^{*} \\
* *\end{array}$ & 0.000 & $\begin{array}{l}0.004^{*} \\
\quad *\end{array}$ & $\begin{array}{c}0.006^{* *} \\
*\end{array}$ & $\begin{array}{c}0.009^{*} \\
* *\end{array}$ \\
\hline & & $(0.005)$ & $(0.006)$ & $(0.002)$ & $(0.002)$ & $(0.002)$ & $(0.002)$ & $(0.002)$ & (0.004) & $(0.004)$ & $(0.009)$ & $\begin{array}{c}(0.004 \\
)\end{array}$ & $(0.001)$ & $(0.002)$ & $(0.002)$ & $(0.003)$ \\
\hline \multirow[t]{2}{*}{ Oth job } & \multirow[t]{2}{*}{$\delta_{4}$} & 0.013 & $\begin{array}{l}0.226^{*} \\
* *\end{array}$ & -0.024 & -0.083 & 0.026 & -0.017 & $\begin{array}{l}-0.080 \\
* * *\end{array}$ & $\begin{array}{c}0.230^{*} \\
* *\end{array}$ & 0.072 & -0.111 & 0.072 & $0.043^{*}$ & 0.033 & $0.135^{*}$ & 0.008 \\
\hline & & $(0.103)$ & $(0.087)$ & $(0.066)$ & $(0.111)$ & $(0.078)$ & $(0.043)$ & $(0.037)$ & $(0.079)$ & $(0.096)$ & $(0.124)$ & $\begin{array}{c}(0.115 \\
)\end{array}$ & $(0.032)$ & $(0.045)$ & $(0.093)$ & $(0.062)$ \\
\hline \multirow[t]{2}{*}{ Irrigation } & \multirow[t]{2}{*}{$\delta_{5}$} & $\begin{array}{l}-0.475 \\
* * *\end{array}$ & $\begin{array}{c}-0.441 \\
* * *\end{array}$ & $\begin{array}{c}0.369^{*} \\
* *\end{array}$ & $\begin{array}{l}-0.776 \\
* * *\end{array}$ & 0.051 & $\begin{array}{c}0.090^{*} \\
*\end{array}$ & $\begin{array}{l}-0.127 \\
* * *\end{array}$ & -0.068 & $-0.176^{*}$ & $2.344^{*}$ & 0.009 & 0.028 & $0.078^{*}$ & $0.272^{* *}$ & -0.038 \\
\hline & & $(0.119)$ & $(0.170)$ & $(0.073)$ & $(0.252)$ & $(0.073)$ & $(0.041)$ & $(0.035)$ & $(0.060)$ & $(0.118)$ & $(1.525)$ & $\begin{array}{c}(0.132 \\
)\end{array}$ & $(0.028)$ & $(0.057)$ & $(0.137)$ & $(0.076)$ \\
\hline \multirow[t]{2}{*}{ Financial } & \multirow[t]{2}{*}{$\delta_{6}$} & $1.062^{*}$ & $\begin{array}{l}0.218^{*} \\
*\end{array}$ & -0.001 & -0.033 & $0.124^{*}$ & $\begin{array}{l}0.143 * \\
*\end{array}$ & $\begin{array}{c}1.607^{*} \\
* *\end{array}$ & $\begin{array}{l}0.811^{*} \\
* *\end{array}$ & $\begin{array}{c}1.455^{*} \\
* *\end{array}$ & 0.236 & $\begin{array}{c}0.567^{*} \\
* *\end{array}$ & $\begin{array}{l}6.661^{*} \\
* *\end{array}$ & $0.133^{*}$ & $-0.124^{*}$ & -0.047 \\
\hline & & $(0.652)$ & $(0.104)$ & $(0.102)$ & $(0.058)$ & $(0.086)$ & $(0.063)$ & $(0.108)$ & $(0.225)$ & $(0.461)$ & $(0.220)$ & $\begin{array}{c}(0.183 \\
)\end{array}$ & $(0.224)$ & $(0.088)$ & $(0.079)$ & $(0.078)$ \\
\hline \multirow[t]{2}{*}{ Govt assist } & \multirow[t]{2}{*}{$\delta_{7}$} & $\begin{array}{l}0.229^{*} \\
\quad *\end{array}$ & $\begin{array}{c}-0.289 \\
* *\end{array}$ & 0.033 & $\begin{array}{c}0.250^{*} \\
* *\end{array}$ & -0.109 & $\begin{array}{l}-0.166 \\
* * *\end{array}$ & -0.016 & -0.097 & $-0.161^{*}$ & 0.121 & 0.018 & $0.046^{*}$ & $0.090^{*}$ & 0.052 & $\begin{array}{c}-0.203 \\
*\end{array}$ \\
\hline & & $(0.138)$ & $(0.135)$ & $(0.150)$ & $(0.069)$ & $(0.104)$ & $(0.057)$ & $(0.037)$ & $(0.079)$ & $(0.114)$ & $(0.131)$ & $\begin{array}{c}(0.121 \\
)\end{array}$ & $(0.030)$ & $(0.062)$ & $(0.109)$ & $(0.126)$ \\
\hline \multirow[t]{2}{*}{ Drought } & \multirow[t]{2}{*}{$\delta_{8}$} & 0.056 & $\begin{array}{c}0.335^{*} \\
* *\end{array}$ & $-0.173^{*}$ & $\begin{array}{c}-0.127 \\
*\end{array}$ & $0.330^{* * *}$ & -0.030 & -0.045 & $\begin{array}{c}0.175^{*} \\
*\end{array}$ & 0.022 & $\begin{array}{l}0.859^{*} \\
*\end{array}$ & $\begin{array}{c}0.302 * \\
*\end{array}$ & $\begin{array}{l}-0.098^{*} \\
\quad * *\end{array}$ & -0.024 & $\begin{array}{c}0.606^{* *} \\
*\end{array}$ & $\begin{array}{c}0.193^{*} \\
*\end{array}$ \\
\hline & & $(0.150)$ & $(0.109)$ & $(0.113)$ & $(0.089)$ & $(0.076)$ & $(0.055)$ & $(0.097)$ & $(0.098)$ & $(0.148)$ & $(0.394)$ & $\begin{array}{c}(0.136 \\
)\end{array}$ & $(0.030)$ & $(0.062)$ & $(0.133)$ & $(0.102)$ \\
\hline \multirow[t]{2}{*}{ Flood } & \multirow[t]{2}{*}{$\delta_{9}$} & -0.206 & $\begin{array}{c}0.423^{*} \\
* *\end{array}$ & $0.208^{*}$ & $0.132 *$ & $0.465^{* * *}$ & 0.000 & $\begin{array}{c}0.371^{*} \\
* *\end{array}$ & $\begin{array}{c}0.271 * \\
*\end{array}$ & -0.339 & 0.000 & $\begin{array}{c}0.445^{*} \\
* *\end{array}$ & -0.033 & $\begin{array}{l}-0.499 \\
* * *\end{array}$ & $\begin{array}{c}-0.580^{*} \\
* *\end{array}$ & $0.148^{*}$ \\
\hline & & $(0.281)$ & $(0.148)$ & $(0.143)$ & $(0.093)$ & $(0.144)$ & $(0.098)$ & $(0.062)$ & $(0.126)$ & $(0.283)$ & $(1.000)$ & $\begin{array}{c}(0.168 \\
)\end{array}$ & $(0.028)$ & $(0.212)$ & $(0.145)$ & (0.098) \\
\hline \multirow[t]{2}{*}{ Cult area } & \multirow[t]{2}{*}{$\delta_{10}$} & 0.199 & $\begin{array}{l}0.498^{*} \\
* *\end{array}$ & $\begin{array}{l}-0.417^{*} \\
\quad * *\end{array}$ & $\begin{array}{c}1.074 * \\
* *\end{array}$ & $0.203^{* *}$ & $\begin{array}{c}0.596^{*} \\
* *\end{array}$ & $\begin{array}{c}0.762 * \\
* *\end{array}$ & $\begin{array}{c}1.357 * \\
* *\end{array}$ & -0.156 & $\begin{array}{l}0.634^{*} \\
* *\end{array}$ & $\begin{array}{c}0.325^{*} \\
*\end{array}$ & $\begin{array}{c}0.026^{*} \\
*\end{array}$ & $\begin{array}{c}0.176^{*} \\
* *\end{array}$ & 0.054 & $\begin{array}{l}0.194 * \\
*\end{array}$ \\
\hline & & $(0.242)$ & $(0.176)$ & $(0.128)$ & $(0.168)$ & $(0.105)$ & $(0.117)$ & $(0.074)$ & $(0.313)$ & $(0.522)$ & $(0.153)$ & $\begin{array}{c}(0.157 \\
)\end{array}$ & $(0.015)$ & $(0.068)$ & $(0.087)$ & $(0.099)$ \\
\hline \multirow[t]{2}{*}{ Labor ratio } & \multirow[t]{2}{*}{$\delta_{11}$} & $\begin{array}{l}0.906^{*} \\
* *\end{array}$ & $\begin{array}{c}1.425^{*} \\
* *\end{array}$ & $\begin{array}{l}0.917^{*} \\
* *\end{array}$ & $\begin{array}{c}0.669^{*} \\
* *\end{array}$ & $1.086 * * *$ & $\begin{array}{c}0.832^{*} \\
* *\end{array}$ & -0.001 & $\begin{array}{c}1.046^{*} \\
* *\end{array}$ & -0.088 & -0.303 & $\begin{array}{c}0.612^{*} \\
* *\end{array}$ & $\begin{array}{l}0.342 * \\
* *\end{array}$ & $\begin{array}{l}0.715^{*} \\
* *\end{array}$ & $\begin{array}{c}0.642^{* *} \\
*\end{array}$ & $\begin{array}{c}1.824^{*} \\
* *\end{array}$ \\
\hline & & $(0.274)$ & $(0.381)$ & $(0.192)$ & $(0.148)$ & $(0.170)$ & $(0.111)$ & $(0.077)$ & $(0.207)$ & $(0.271)$ & $(0.344)$ & $\begin{array}{c}(0.223 \\
)\end{array}$ & $(0.066)$ & $(0.131)$ & $(0.158)$ & $(0.303)$ \\
\hline \multirow[t]{2}{*}{$\begin{array}{l}\text { Sigma-squa } \\
\text { red }\end{array}$} & \multirow[t]{2}{*}{$\sigma^{2}$} & $\begin{array}{c}0.058^{*} \\
* *\end{array}$ & $\begin{array}{c}0.268^{*} \\
* *\end{array}$ & $\begin{array}{c}0.069^{*} \\
* *\end{array}$ & $\begin{array}{c}0.082^{*} \\
* *\end{array}$ & $0.167^{* * *}$ & $\begin{array}{c}0.208^{*} \\
* *\end{array}$ & $\begin{array}{c}0.346^{*} \\
* *\end{array}$ & $\begin{array}{c}0.299 * \\
* *\end{array}$ & $\begin{array}{c}0.267^{*} \\
* *\end{array}$ & $\begin{array}{c}0.079^{*} \\
* *\end{array}$ & $\begin{array}{c}0.084^{*} \\
* *\end{array}$ & $\begin{array}{c}0.018^{*} \\
* *\end{array}$ & $\begin{array}{c}0.046^{*} \\
* *\end{array}$ & $\begin{array}{l}0.053^{* *} \\
*\end{array}$ & $\begin{array}{c}0.169^{*} \\
* *\end{array}$ \\
\hline & & $(0.023)$ & $(0.067)$ & $(0.012)$ & $(0.008)$ & $(0.029)$ & (0.033) & $(0.018)$ & $(0.072)$ & $(0.077)$ & $(0.024)$ & $\begin{array}{c}(0.020 \\
)\end{array}$ & $(0.002)$ & $(0.009)$ & $(0.012)$ & $(0.046)$ \\
\hline \multirow[t]{2}{*}{ gamma } & \multirow[t]{2}{*}{$\gamma$} & $\begin{array}{c}0.818^{*} \\
* *\end{array}$ & $\begin{array}{c}0.938^{*} \\
* *\end{array}$ & $\begin{array}{l}0.475^{*} \\
* *\end{array}$ & $\begin{array}{c}0.699^{*} \\
* *\end{array}$ & $0.912^{* * *}$ & $\begin{array}{l}0.951 * \\
* *\end{array}$ & $\begin{array}{c}0.999 * \\
* *\end{array}$ & $\begin{array}{l}0.930^{*} \\
* *\end{array}$ & $\begin{array}{l}0.991^{*} \\
* *\end{array}$ & $\begin{array}{c}0.886^{*} \\
* *\end{array}$ & 0.184 & 0.080 & 0.445 & $\begin{array}{c}0.473^{* *} \\
*\end{array}$ & $\begin{array}{c}0.882^{*} \\
* *\end{array}$ \\
\hline & & $(0.107)$ & $(0.018)$ & $(0.129)$ & $(0.051)$ & $(0.042)$ & $(0.011)$ & $(0.000)$ & $(0.019)$ & $(0.008)$ & $(0.076)$ & $\begin{array}{c}(0.234 \\
)\end{array}$ & $(2.014)$ & $(0.384)$ & $(0.149)$ & $(0.057)$ \\
\hline $\begin{array}{l}\text { Log-likelih } \\
\text { ood }\end{array}$ & & 75.02 & 67.66 & 25.92 & 69.53 & -54.18 & 170.72 & 665.55 & 38.92 & 36.16 & 36.21 & -24.35 & 96.59 & 57.62 & 35.95 & 88.39 \\
\hline
\end{tabular}

In terms of source of financing, the financial coefficients show significant and positive signs, which mean that as the source of financing comes from farmer, the production will be less efficient compared to the case of external source of financing. A limited amount of fund of farmer will constrain farmer in applying better inputs such 
seeds, fertilizer, tractor machine, and other materials in the rice farming, therefore the source of financing in rice farming influences efficiency. Furthermore, the government assistance has a different effect on technical efficiency. In SUMUT, JABAR, BANTEN and SULSEL government has a positive influence to increase the efficiency. On the other hand, in the others, the government assistance may not have impact to improve the efficiency.

Another appealing result is that the cultivated area and labour ratio have a similar effect on technical efficiency. On average, a wider land area a lower technical efficiency will be. It could occur because an increase of land used may not be followed by an increase of other important inputs hence the economic scale cannot be exhibited. This circumstance supports the diminishing return condition resulted from production function estimation. Similarly, when the ratio of labour engaged is higher, the technical efficiency tends to be lower.

Climatic factors or the season is also a factor that is important in the process of rice farming in Indonesia. This factor indicated by the dummy variable of dry season and the rainy season. Based on the estimates, when there is a dry season, some provinces experience a lower efficiency in rice farming. Meanwhile, during the rainy season, the impact varies among provinces. But in general, in the case of flood, the level of production efficiency is also decreased significantly.

\subsection{Technical Efficiency Indexes}

The average farm-level technical efficiencies of the 15 provinces are predicted based on the maximum-likelihood estimates. The estimates are presented in Table 7. The results show a wide variation in the level of technical efficiencies across provinces. For example, the minimum and maximum technical efficiencies in the 15 provinces are 11 per cent and 100 per cent, respectively. With respect to mean value, out of the sample of 15 provinces, 47 per cent have technical efficiency of 80 per cent or below, while the remaining 53 per cent have technical efficiency of higher than 81 per cent. Overall, the mean technical efficiency is about 77 per cent, indicating that the average farm produced only 77 per cent of the maximum attainable output for given input levels in 2008. This shows that there is considerable possibility for enhancing the technical efficiency, and thus productivity as well as the overall rice output. The higher degree of variability of technical efficiency estimates between provinces can be attributed to the instability of farming conditions.

Table 7. Descriptive statistics of predicted technical efficiency indexes

\begin{tabular}{ccccc}
\hline Province & Mean & Minimum & Maximum & Standard deviation \\
\hline ACEH & 0.816 & 0.290 & 0.981 & 0.164 \\
SUMUT & 0.809 & 0.319 & 0.967 & 0.138 \\
SUMBAR & 0.863 & 0.468 & 0.980 & 0.112 \\
SUMSEL & 0.819 & 0.397 & 0.980 & 0.141 \\
LAMPUNG & 0.694 & 0.285 & 0.959 & 0.151 \\
JABAR & 0.783 & 0.311 & 0.975 & 0.157 \\
JATENG & 0.810 & 0.331 & 1.000 & 0.141 \\
JATIM & 0.805 & 0.304 & 0.967 & 0.174 \\
BANTEN & 0.750 & 0.279 & 0.984 & 0.145 \\
BALI & 0.799 & 0.341 & 0.972 & 0.145 \\
NTB & 0.850 & 0.333 & 0.986 & 0.154 \\
KALBAR & 0.317 & 0.106 & 0.986 & 0.138 \\
KALSEL & 0.776 & 0.432 & 0.980 & 0.111 \\
SULTENG & 0.879 & 0.516 & 0.982 & 0.125 \\
SULSEL & 0.820 & 0.311 & 0.970 & $\mathbf{0 . 1 5}$ \\
\hline Average & $\mathbf{0 . 7 7}$ & $\mathbf{0 . 3 3}$ & $\mathbf{6 7 . 5 8}$ & \\
\hline
\end{tabular}

\section{Conclusion}

This study uses stochastic production frontier to estimate farm level technical efficiency using input and output data from 15 provinces in Indonesia in 2008. The results indicate sizeable degree variation of inefficiency in all provinces, which imply considerable possibility for enhancing the technical efficiency, and thus productivity as well as the overall rice output. In general, land input has a significant contribution in most of the provinces. However in some provinces there is a tendency of diminishing return, especially in Java and Sumatera islands.

The study also analyses the inefficiency effects to evaluate the factors influencing the inefficiency. Results indicate that improving farmer's income will increase the technical efficiency of rice farming by allowing farmer to improve the quality of their production factors. Further results also show that giving incentive to people in productive age to work in the rice farming will enhance the technical efficiency as well as productivity of rice 
production. The improvement of government assistance, especially with respect to financial aspect will also enhance the technical efficiency, since the assistantships will reduce the farmer's constraint in applying better inputs such seeds, fertilizer, tractor machine, and other materials in the rice farming.

\section{References}

Aigner, D., Lovell, K. C. A., \& Schmidt, P. (1977). Formulation and Estimation of Stochastic Frontier Production Function Models. Journal of Econometrics, 6, 21-37.

Balcombe, K., Lain, F., Mizanur, R., \& Laurence, S. (2007). Examining the technical efficiency of rice producers in Bangladesh. Journal of International Development, 19(1), 1-16. http://dx.doi.org/10.1002/jid.1284

Battese, G. E., \& Coelli, T. J. (1995). A Model for Technical Inefficiency Effects in a Stochastic Frontier Production Function for Panel data. Empirical Economics, 20, 325-332.

Battese, G. E., \& Coelli, T. J. (1992). Frontier Production Function, Technical Efficiency and Panel Data: With Application to Paddy Farmer in India. Journal of Productivity Analysis, 3, 153-169.

Battese, G. E., Coelli, T. J., \& Colby, T. C. (1989). Estimation of Frontier Production Functions and the Efficiencies of Indian Farms Using Panel Data from ICRISAT's Village Level Studies.

Battese, G. E., \& Coelli, T. J. (1988). Prediction of Firm-Level Technical Efficiencies with a Generalized Frontier Production and Panel Data. Journal of Econometrics, 38, 387-399.

Statistik, B. P. (2007). Statistik Pertanian [Indonesia Agriculture Statistics].

Bravo-Ureta B. E., \& Pinheiro, A. E. (1993). Efficiency Analysis of Developing Country Agriculture: A Review of the Frontier Function Literature. Agriculture and resources Economic Review, 22, 88-101.

Brazdik, F. (2006). Non-parametric analysis of technical efficiency: Factors affecting efficiency of West Java rice farms. Working Paper Series No. 286. Charles University Center for Economic Research and Graduate Education Academy of Sciences of the Czech Republic Economics Institute (CERGE-EI).

Coelli, T., Rahman, S., \& Thirtle, C. (2002). Technical, Allocative, Cost and Scale Efficiencies in Bangladesh Rice Cultivation: A Non-parametric Approach. Journal of Agricultural Economics, 53(3), 607-626. http://dx.doi.org/10.1111/j.1477-9552.2002.tb00040.x

Dhungana, B. R., Nuthall, P. L., \& Nartea, G. V. (2004). Measuring the economic inefficiency of Nepalese rice farms using data envelopment analysis. The Australian Journal of Agricultural and Resource Economics, 48, 347-369. http://dx.doi.org/10.1111/j.1467-8489.2004.00243.x

Fabiosa, J. F., Jensen, H. H., \& Yan, D. (2004). Do Macroeconomic Shocks Impact the Economic Efficiency of Small Farmers? The Case of Wetland Rice Farmers in Indonesia. Working Paper 04-WP 364 Center for Agricultural and Rural Development Iowa State University.

Idiong, I. C. (2007). Estimation of Farm Level Technical Efficiency in Small scale Swamp Rice Production in Cross River State of Nigeria: A Stochastic Frontier Approach. World Journal of Agricultural Sciences, 3, 653-658.

Javed, M. I., Adil, S. A., Ali, A., \& Raza, M. A. (2010). Measurement of Technical Efficiency of Rice-Wheat System in Punjab, Pakistan Using DEA Technique. Journal of Agricultural Resources, 48, 227-238.

Jondrow, J., Lovell, C. A. K., Materov, I. S., \& Schmidt, P. (1982). On the Estimation of Technical Efficiency in the Stochastic Frontier Production Function Model. Journal of Econometrics, 19, 233-238.

Khai, H. V., \& Yabe, M. (2011). Technical Efficiency Analysis of Rice Production in Vietnam. Journal ISSAAS, 17, 135-146.

Khan, A., Huda, F. A., \& Alam, A. (2010). Farm Household Technical Efficiency: A Study on Rice Producers in Selected Areas of Jamalpur District in Bangladesh. European Journal of Social Sciences, 14, 262-271.

Krasachat, W. (2003). Technical Efficiencies of Rice Farms in Thailand: A Nonparametric Approach. Paper presented to the 2003 Hawaii International Conference on Business, Honolulu, June 18-2. Retrieved from http://www.hicbusiness.org/biz2003proceedings/Wirat\%20Krasachat.pdf

Meeusen, \& van den Broeck, J. (1977). Efficiency Estimation from Cobb-Douglas Production Functions with Composed Error. International Economic Review, 18, 435-444.

Rada, N. E., Buccola, S. T., \& Fuglie, K. O. (2010). Uncovering Productivity Growth in the Disaggregate: Indonesia's Dueling Agricultural Sub-Sectors. Paper presented at the Agricultural \& Applied Economics 
Association 2010 AAEA, CAES, \& WAEA Joint Annual Meeting.

Rahman, S. (2010). Women's Labour Contribution to Productivity and Efficiency in Agriculture: Empirical Evidence From Bangladesh. Journal of Agricultural Economics, 61(2), 318-342. http://dx.doi.org/10.1111/ j.1477-9552.2010.00243.x

Rahman, S., \& Rahman, M. (2009). Impact of land fragmentation and resource ownership on productivity and efficiency: The case of rice producers in Bangladesh. Land Use Policy, 26(1), 95-103. http://dx.doi.org/10.1016/j.landusepol.2008.01.003

Stevenson, R. E. (1980). Likelihood Functions for Generalized Stochastic Frontier Estimation. Journal of Econometrics, 13, 57-66.

Tan, S., Heerink, N., Kuyvenhoven, A., \& Qu, F. (2010). Impact of land fragmentation on rice producers' technical efficiency in South-East China. NJAS - Wageningen Journal of Life Sciences, 57(2), 117-123. http://dx.doi.org/10.1016/j.njas.2010.02.001

Tian, W., \& Wan, G. H. (2000). Technical efficiency and its determinants in China's grain production. Journal of Productivity Analysis, 13, 159-174.

Wadud, A., \& White, B. (2000). Farm household efficiency in Bangladesh: A comparison of stochastic frontier and DEA methods. Applied Economics, 32(13), 1665-1673. http://dx.doi.org/10.1080/000368400421011

World Bank. (2010). Indonesia agriculture public expenditure review. World Bank

Xu, X., \& Jeffry, S. R. (1998). Efficiency and technical progress in traditional and modern agriculture: Evidence from rice production in China. Agricultural Economics, 18, 157-165. http://dx.doi.org/10.1016/S0169-5150 (98)80004-2

Yao, R. T., \& Shively, G. E. (2007). Technical Change and Productive Efficiency: Irrigated Rice in the Philippines. Asian Economic Journal, 21(2), 155-168. http://dx.doi.org/10.1111/j.1467-8381.2007.00252.x

\section{Copyrights}

Copyright for this article is retained by the author(s), with first publication rights granted to the journal.

This is an open-access article distributed under the terms and conditions of the Creative Commons Attribution license (http://creativecommons.org/licenses/by/3.0/). 